\title{
Algoriphagus locisalis sp. nov., isolated from a marine solar saltern
}

Correspondence

Jung-Hoon Yoon

jhyoon@kribb.re.kr

\author{
Jung-Hoon Yoon, So-Jung Kang and Tae-Kwang Oh \\ Korea Research Institute of Bioscience and Biotechnology (KRIBB), PO Box 115, Yusong, \\ Taejon, Republic of Korea
}

\begin{abstract}
Two Gram-negative, rod-shaped, non-motile bacterial strains, MSS $-170^{\top}$ and MSS-171, were isolated from sea water of a marine solar saltern of the Yellow Sea, Korea, and characterized by using a polyphasic taxonomic approach. The two isolates grew optimally at $30^{\circ} \mathrm{C}$ and in the presence of $2 \%(\mathrm{w} / \mathrm{v}) \mathrm{NaCl}$. They were characterized chemotaxonomically as having MK-7 as the predominant menaquinone and major amounts of fatty acids iso- $\mathrm{C}_{15: 0}$ and $\mathrm{C}_{16: 1} \omega 7 \mathrm{c}$ and/or iso- $\mathrm{C}_{15: 0} 2-\mathrm{OH}$. The DNA G $+\mathrm{C}$ content of each of the two strains was $42 \mathrm{~mol} \%$. Phylogenetic analyses based on 16S rRNA gene sequences showed that the two strains fall within the evolutionary radiation enclosed by the genus Algoriphagus. Strains MSS- $170^{\top}$ and MSS-171 had identical 16S rRNA gene sequences and exhibited a mean DNA-DNA relatedness level of $93 \%$. The two strains exhibited $16 \mathrm{~S}$ rRNA gene sequence similarity levels of $96 \cdot 4-98 \cdot 9 \%$ with respect to the type strains of recognized Algoriphagus species. DNA-DNA relatedness levels between the two strains and the type strains of six Algoriphagus species were less than $35 \%$. On the basis of phenotypic data and phylogenetic and genetic distinctiveness, strains MSS-170 and MSS-171 were classified in the genus Algoriphagus as members of a novel species, for which the name Algoriphagus locisalis sp. nov. is proposed. The type strain is MSS $-170^{\top}$ ( $=$ KCTC $12310^{\top}=$ JCM $12597^{\top}$ ).
\end{abstract}

The genus Algoriphagus was first described by Bowman et al. (2003). At present, the genus comprises seven species with validly published names: Algoriphagus ratkowskyi (Bowman et al., 2003), A. aquimarinus, A. chordae and A. winogradskyi (Nedashkovskaya et al., 2004), A. halophilus (Yi \& Chun, 2004; Nedashkovskaya et al., 2004), A. antarcticus (Van Trappen et al., 2004) and A. yeomjeoni (Yoon et al., 2005). In the study, we report on the taxonomic characterization of two slightly halophilic, orange-pigmented, Algoriphaguslike bacterial strains, MSS- $170^{\mathrm{T}}$ and MSS-171, which were isolated from sea water of a marine solar saltern of the Yellow Sea in Korea.

Sea water collected from a marine solar saltern of the Yellow Sea, Korea, was used as the source for the isolation of bacterial strains. Strains MSS- $170^{\mathrm{T}}$ and MSS-171 were isolated by using the standard dilution-plating technique on marine agar 2216 (MA; Difco) at $25^{\circ} \mathrm{C}$. A. ratkowskyi CIP $107452^{\mathrm{T}}$ was obtained from the Collection de l'Institut Pasteur (Paris, France). A. aquimarinus LMG $21971^{\mathrm{T}}$, A. chordae LMG $21970^{\mathrm{T}}$, A. winogradskyi LMG $21969^{\mathrm{T}}$ and A. antarcticus LMG $21980^{\mathrm{T}}$ were obtained from the Laboratorium voor Microbiologie, Universiteit Gent

The GenBank/EMBL/DDBJ accession numbers for the 16S rRNA gene sequences of strains MSS-170 ${ }^{\top}$ and MSS-171 are AY835922 and AY835923, respectively.
(Ghent, Belgium). A. yeomjeoni MSS- $160^{\mathrm{T}}$ was obtained from the study of Yoon et al. (2005). The morphological and physiological characteristics of strains MSS $-170^{\mathrm{T}}$ and MSS-171 were investigated on MA at $30^{\circ} \mathrm{C}$. Cell morphology was examined by using light microscopy (E600; Nikon) and transmission electron microscopy. The presence of flagella was investigated by using transmission electron microscopy with cells from exponentially growing cultures. Gliding motility was determined as described by Bowman (2000). The Gram-reaction was determined by using the bioMérieux Gram Stain kit according to the manufacturer's instructions. Growth at various temperatures (4$40^{\circ} \mathrm{C}$ ) was measured on MA. The $\mathrm{pH}$ range for growth was determined in marine broth 2216 (Difco) that had been adjusted to various $\mathrm{pH}$ values (initial $\mathrm{pH} 4 \cdot 5$, rising to $\mathrm{pH} 10.5$ at intervals of $0.5 \mathrm{pH}$ units). The $\mathrm{pH}$ was adjusted prior to sterilization to various levels by the addition of $\mathrm{Na}_{2} \mathrm{CO}_{3}$. Growth under anaerobic conditions was determined after incubation in a Forma anaerobic chamber on MA and MA supplemented with nitrate, both of which had been prepared anaerobically using nitrogen. Catalase and oxidase activities and hydrolysis of casein and starch were determined as described by Cowan \& Steel (1965). Hydrolysis of hypoxanthine, tyrosine and xanthine was tested on MA using the substrate concentrations described by Cowan \& Steel (1965). Hydrolysis of aesculin, gelatin, urea and Tweens 20, 40, 60 and 80 and nitrate reduction 
were studied as described previously (Lanyi, 1987) but with the modification that artificial sea water was used for preparation of the media. The artificial sea water contained the following (per litre distilled water): $23.6 \mathrm{~g} \mathrm{NaCl}, 0.64 \mathrm{~g}$ $\mathrm{KCl}, 4.53 \mathrm{~g} \mathrm{MgCl}_{2} \cdot 6 \mathrm{H}_{2} \mathrm{O}, 5.94 \mathrm{~g} \mathrm{MgSO}_{4} .7 \mathrm{H}_{2} \mathrm{O}$ and $1.3 \mathrm{~g}$ $\mathrm{CaCl}_{2} \cdot 2 \mathrm{H}_{2} \mathrm{O}$ (Bruns et al., 2001). $\mathrm{H}_{2} \mathrm{~S}$ production was tested as described by Bruns et al. (2001). The presence of flexirubin pigment was investigated as described by Reichenbach (1992). Susceptibility to antibiotics was tested on MA plates by using discs containing the following antibiotics: ampicillin $(10 \mu \mathrm{g})$, benzylpenicillin $(10 \mu \mathrm{g})$, carbenicillin $(100 \mu \mathrm{g})$, gentamicin $(10 \mu \mathrm{g})$, kanamycin $(30 \mu \mathrm{g})$, lincomycin $(15 \mu \mathrm{g})$, neomycin $(30 \mu \mathrm{g})$, oleandomycin $(15 \mu \mathrm{g})$, polymyxin B (300 U), streptomycin $(10 \mu \mathrm{g})$, chloramphenicol $(100 \mu \mathrm{g})$ or tetracycline $(30 \mu \mathrm{g})$. Acid production from carbohydrates was determined as described by Leifson (1963). Utilization of various substrates for growth was determined as described by Yurkov et al. (1994). The morphological, cultural, physiological and biochemical characteristics of strains MSS- $170^{\mathrm{T}}$ and

Table 1. Differential phenotypic characteristics of Algoriphagus species

Species: 1, A. locisalis sp. nov.; 2, A. winogradskyi; 3, A. yeomjeoni; 4, A. aquimarinus; 5, A. ratkowskyi; 6, A. chordae; 7, A. antarcticus; 8, A. halophilus. Data are from Bowman et al. (2003), Yi \& Chun (2004), Nedashkovskaya et al. (2004), Van Trappen et al. (2004) and Yoon et al. (2005). Symbols: +, positive; -, negative; W, weakly positive; V, variable; ND, not determined. Data in parentheses are for the type strain. All species are Gram-negative and rod-shaped and positive for catalase and oxidase. All species are negative for gliding motility, flexirubin pigment production, $\mathrm{H}_{2} \mathrm{~S}$ and indole production, utilization of citrate, and susceptibility to ampicillin, benzylpenicillin, gentamicin, kanamycin, neomycin, polymyxin $\mathrm{B}$ and streptomycin.

\begin{tabular}{|c|c|c|c|c|c|c|c|c|}
\hline Characteristic & 1 & 2 & 3 & 4 & 5 & 6 & 7 & 8 \\
\hline Nitrate reduction & - & + & - & - & - & - & - & - \\
\hline $\mathrm{NaCl}$ requirement for growth & + & - & + & - & + & + & ND & - \\
\hline Optimal temp. for growth $\left({ }^{\circ} \mathrm{C}\right)$ & 30 & $25-28$ & $25-30$ & $23-25$ & $16-19$ & $23-25$ & 20 & 35 \\
\hline \multicolumn{9}{|l|}{ Growth in/at: } \\
\hline $10 \% \mathrm{NaCl}$ & - & - & - & + & - & + & - & - \\
\hline $37^{\circ} \mathrm{C}$ & - & + & - & - & - & - & - & + \\
\hline \multicolumn{9}{|l|}{ Hydrolysis of: } \\
\hline Agar & - & + & - & + & - & + & - & - \\
\hline Casein & - & - & + & + & $\mathrm{V}$ & - & - & - \\
\hline Gelatin & - & + & $\mathrm{V}(+)$ & + & - & - & - & + \\
\hline Starch & - & + & - & - & $\mathrm{V}$ & - & - & + \\
\hline Tween 80 & + & - & + & + & - & - & ND & + \\
\hline \multicolumn{9}{|l|}{ Acid production from: } \\
\hline L-Arabinose & + & - & - & - & + & - & - & - \\
\hline D-Cellobiose & + & + & + & + & + & + & ND & - \\
\hline D-Galactose & + & + & + & - & + & + & ND & - \\
\hline D-Glucose & + & + & + & + & + & + & - & + \\
\hline Lactose & + & + & + & + & - & + & ND & - \\
\hline Maltose & + & + & + & - & + & + & $\mathrm{ND}$ & + \\
\hline D-Melibiose & + & + & + & + & + & + & - & - \\
\hline L-Rhamnose & + & + & + & + & + & + & - & - \\
\hline Sucrose & + & + & + & + & - & + & - & + \\
\hline D-Xylose & + & + & + & + & + & + & ND & + \\
\hline \multicolumn{9}{|l|}{ Utilization of: } \\
\hline L-Arabinose & - & + & - & + & + & + & - & + \\
\hline D-Glucose & + & + & + & + & + & + & - & + \\
\hline D-Mannose & + & + & + & + & + & + & - & + \\
\hline Malate & - & - & - & - & $\mathrm{V}$ & - & - & - \\
\hline \multicolumn{9}{|l|}{ Susceptibility to: } \\
\hline Carbenicillin & - & $\mathrm{V}$ & + & + & + & - & ND & + \\
\hline Lincomycin & + & $\mathrm{V}$ & + & + & + & + & ND & + \\
\hline Oleandomycin & + & + & + & + & + & - & ND & + \\
\hline Tetracycline & - & $\mathrm{V}$ & - & + & + & - & $\mathrm{ND}$ & + \\
\hline DNA G $+\mathrm{C}$ content $(\mathrm{mol} \%)$ & 42 & $39-42$ & 41 & 41 & $35-37$ & $37-40$ & $40-41$ & 37 \\
\hline
\end{tabular}


MSS-171 are shown in Table 1 or are given in the species description (see below). The two strains were similar in most phenotypic characteristics, except for the utilization of D-trehalose and acid production from D-trehalose.

Cell biomass for isoprenoid quinone analysis and for DNA extraction was obtained from cultivation for 2 days in marine broth 2216 at $30^{\circ} \mathrm{C}$. Chromosomal DNA was isolated and purified as described previously (Yoon et al., 1996), with the exception that RNase T1 was applied in combination with RNase A to minimize the contamination with RNA. The $16 \mathrm{~S}$ rRNA gene was amplified by a PCR using two universal primers as described previously (Yoon et al., 1998). Sequencing of the $16 \mathrm{~S}$ rRNA gene and phylogenetic analysis were performed as described previously (Yoon et al., 2003). Isoprenoid quinones were analysed as described by Komagata \& Suzuki (1987), using reversedphase HPLC. For fatty acid methyl ester analysis, cell mass of each of the two isolates was harvested from agar plates after incubation for 3 days on $\mathrm{MA}$ at $30^{\circ} \mathrm{C}$. The fatty acid methyl esters were extracted and prepared according to the standard protocol of the MIDI/Hewlett Packard Microbial Identification System (Sasser, 1990). The DNA $\mathrm{G}+\mathrm{C}$ content was determined by the method of Tamaoka \& Komagata (1984), with the modification that DNA was hydrolysed and the resultant nucleotides were analysed by reversed-phase HPLC. DNA-DNA hybridization was performed fluorometrically by the method of Ezaki et al. (1989), using photobiotin-labelled DNA probes and microdilution wells. Hybridization was performed with five replications for each sample. The highest and lowest values obtained in each sample were excluded; the means of the remaining three values are quoted as DNA-DNA relatedness values.

The almost-complete 16S rRNA gene sequences of strains MSS- $170^{\mathrm{T}}$ and MSS-171 determined in this study each comprised 1477 nucleotides, representing approximately $96 \%$ of the Escherichia coli 16S rRNA gene sequence. The $16 \mathrm{~S}$ rRNA gene sequences of strains MSS $-170^{\mathrm{T}}$ and MSS171 were identical. Comparative $16 \mathrm{~S}$ rRNA gene sequence analyses showed that strains MSS- $170^{\mathrm{T}}$ and MSS-171 are phylogenetically most related to Algoriphagus species (Fig. 1). In the phylogenetic tree based on the neighbourjoining algorithm, strains MSS- $170^{\mathrm{T}}$ and MSS-171 fell within the radiation of the cluster comprising Algoriphagus species (Fig. 1). Similar tree topologies were found in the trees generated with the maximum-likelihood and maximum-parsimony algorithms (data not shown). Similarity values between the $16 \mathrm{~S}$ rRNA gene sequences of the two isolates and those of recognized Algoriphagus species ranged from $96 \cdot 4 \%$ (A. halophilus IMSNU $14013^{\mathrm{T}}$ ) to $98.9 \%$ (A. winogradskyi KMM $3956^{\mathrm{T}}$ ). Sequence similarities to other species included in the phylogenetic analysis were below $94.6 \%$ (Fig. 1).

The chemotaxonomic properties, i.e. predominant menaquinone, fatty acid profiles and DNA G $+\mathrm{C}$ content, support the result of the monothetic phylogenetic classification,

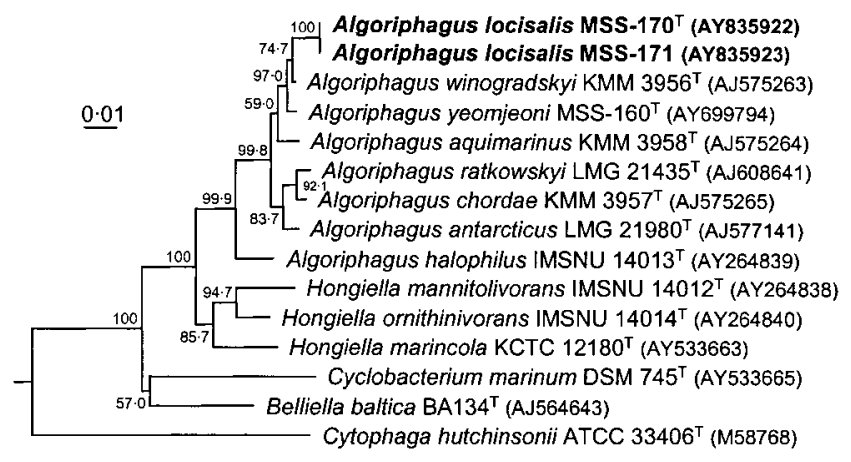

Fig. 1. Neighbour-joining phylogenetic tree, based on $16 \mathrm{~S}$ rRNA gene sequences, showing the positions of strains MSS$170^{\top}$ and MSS-171 and some other related taxa. Bootstrap values (1000 replications) are shown as percentages at each node only if they are $50 \%$ or greater. Bar, 0.01 substitutions per nucleotide position. Flavobacterium aquatile IAM $12316^{\top}$ was used as the outgroup (not shown).

namely that the two isolates might be members of the genus Algoriphagus (Bowman et al., 2003; Nedashkovskaya et al., 2004; Yoon et al., 2005). The predominant isoprenoid quinone detected in strains MSS- $170^{\mathrm{T}}$ and MSS-171 was MK-7, at a peak area ratio of approximately $96 \%$. The fatty acid profiles of the two isolates were characterized as sharing straight-chain, branched, unsaturated and hydroxy fatty acids in similar amounts; the major fatty acids were iso- $\mathrm{C}_{15: 0}$ and $\mathrm{C}_{16: 1} \omega 7 c$ and/or iso- $\mathrm{C}_{15: 0} 2-\mathrm{OH}$ (Table 2). These fatty acid profiles were similar to those of Algoriphagus species (Table 2). The DNA G $+\mathrm{C}$ contents of strains MSS- $170^{\mathrm{T}}$ and MSS-171 were the same, both being $42 \mathrm{~mol} \%$.

Strains MSS $-170^{\mathrm{T}}$ and MSS-171 exhibited a mean level of DNA-DNA relatedness of $93 \%$ when their DNAs were used individually as labelled DNA probes for cross-hybridization, indicating that the two strains are members of the same genomic species. The two strains exhibited DNA-DNA relatedness levels of 9-35\% with respect to the type strains of the six Algoriphagus species that showed 16S rRNA gene sequence similarity values of more than $97 \cdot 0 \%$ with respect to the two strains (the exception being A. halophilus; see above). In view of the combined phenotypic, phylogenetic and genetic similarity, strains MSS $-170^{\mathrm{T}}$ and MSS-171 were considered as members of the same species. There were some differences between the two strains and recognized Algoriphagus species in terms of phenotypic characteristics (Table 1). The phylogenetic and genetic distinctiveness was sufficient to separate strains MSS- $170^{\mathrm{T}}$ and MSS-171 from other Algoriphagus species with validly published names (Wayne et al., 1987; Stackebrandt \& Goebel, 1994). Therefore, on the basis of the data presented, strains MSS $-170^{\mathrm{T}}$ and MSS-171 should be placed in the genus Algoriphagus as members of a novel species, for which the name Algoriphagus locisalis sp. nov. is proposed. 
Table 2. Cellular fatty acid compositions (\%) of Algoriphagus species

Strains: 1, A. locisalis sp. nov. MSS $-170^{\mathrm{T}} ; 2$, A. locisalis sp. nov. MSS-171; 3, A. winogradskyi KMM $3956^{\mathrm{T}}$; 4, A. yeomjeoni MSS$160^{\mathrm{T}} ; 5$, A. aquimarinus $\mathrm{KMM} 3958^{\mathrm{T}} ; 6$, A. ratkowskyi LMG $21435^{\mathrm{T}}$; 7, A. chordae KMM 3957 ; 8, A. halophilus LMG $22067^{\mathrm{T}}$. Data for reference strains were taken from Nedashkovskaya et al. (2004) and Yoon et al. (2005). Fatty acids that represented less than $0.5 \%$ in all strains are omitted. ND, Not detected.

\begin{tabular}{|c|c|c|c|c|c|c|c|c|}
\hline Fatty acid & 1 & 2 & 3 & 4 & 5 & 6 & 7 & 8 \\
\hline \multicolumn{9}{|c|}{ Straight-chain fatty acids } \\
\hline $\mathrm{C}_{15: 0}$ & $1 \cdot 5$ & $1 \cdot 3$ & $1 \cdot 2$ & $0 \cdot 6$ & $1 \cdot 6$ & $1 \cdot 6$ & $2 \cdot 5$ & $1 \cdot 0$ \\
\hline $\mathrm{C}_{16: 0}$ & $0 \cdot 7$ & $0 \cdot 6$ & $1 \cdot 0$ & $0 \cdot 8$ & $1 \cdot 7$ & $2 \cdot 9$ & $1 \cdot 4$ & ND \\
\hline \multicolumn{9}{|c|}{ Branched fatty acids } \\
\hline iso- $\mathrm{C}_{11: 0}$ & $0 \cdot 7$ & $0 \cdot 8$ & ND & ND & ND & ND & ND & ND \\
\hline anteiso- $\mathrm{C}_{11: 0}$ & $1 \cdot 6$ & $1 \cdot 6$ & $1 \cdot 2$ & ND & $0 \cdot 6$ & $2 \cdot 1$ & $1 \cdot 0$ & $1 \cdot 5$ \\
\hline iso- $\mathrm{C}_{14: 0}$ & $0 \cdot 3$ & $0 \cdot 3$ & $0 \cdot 3$ & $1 \cdot 6$ & $0 \cdot 7$ & $1 \cdot 4$ & $0 \cdot 3$ & $0 \cdot 6$ \\
\hline iso- $\mathrm{C}_{15: 0}$ & $31 \cdot 2$ & $30 \cdot 6$ & $36 \cdot 6$ & $28 \cdot 6$ & $38 \cdot 9$ & $30 \cdot 5$ & $38 \cdot 1$ & $28 \cdot 4$ \\
\hline iso- $\mathrm{C}_{15: 1} \mathrm{G}$ & $0 \cdot 8$ & $0 \cdot 8$ & $2 \cdot 9$ & $\mathrm{ND}$ & $0 \cdot 3$ & $1 \cdot 1$ & ND & ND \\
\hline anteiso- $\mathrm{C}_{15: 0}$ & $0 \cdot 8$ & $0 \cdot 7$ & $1 \cdot 6$ & $1 \cdot 2$ & $3 \cdot 2$ & $3 \cdot 6$ & $1 \cdot 9$ & $2 \cdot 8$ \\
\hline iso- $\mathrm{C}_{16: 0}$ & $3 \cdot 5$ & $3 \cdot 5$ & $3 \cdot 9$ & $4 \cdot 8$ & $2 \cdot 4$ & $3 \cdot 4$ & $5 \cdot 8$ & $7 \cdot 7$ \\
\hline iso- $\mathrm{C}_{16: 1} \mathrm{H}$ & $1 \cdot 6$ & $1 \cdot 4$ & $2 \cdot 1$ & $1 \cdot 9$ & $2 \cdot 4$ & $1 \cdot 7$ & $1 \cdot 5$ & $3 \cdot 5$ \\
\hline iso- $\mathrm{C}_{17: 1} \omega 9 c$ & $2 \cdot 8$ & $2 \cdot 7$ & $4 \cdot 0$ & $2 \cdot 3$ & $5 \cdot 3$ & $1 \cdot 5$ & $4 \cdot 4$ & $9 \cdot 0$ \\
\hline \multicolumn{9}{|c|}{ Unsaturated fatty acids } \\
\hline $\mathrm{C}_{15: 1} \omega 6 c$ & $1 \cdot 6$ & $1 \cdot 5$ & $1 \cdot 3$ & $0 \cdot 8$ & $2 \cdot 3$ & $2 \cdot 1$ & $1 \cdot 0$ & $1 \cdot 8$ \\
\hline $\mathrm{C}_{16: 1} \omega 5 c$ & $3 \cdot 7$ & $3 \cdot 6$ & $3 \cdot 6$ & $3 \cdot 3$ & $5 \cdot 2$ & $5 \cdot 8$ & $3 \cdot 6$ & $3 \cdot 5$ \\
\hline $\mathrm{C}_{17: 1} \omega 6 c$ & $1 \cdot 7$ & $2 \cdot 0$ & $0 \cdot 8$ & $1 \cdot 0$ & $0 \cdot 7$ & $0 \cdot 5$ & $1 \cdot 2$ & $3 \cdot 4$ \\
\hline \multicolumn{9}{|c|}{ Hydroxy fatty acids } \\
\hline iso- $\mathrm{C}_{15: 0} 3-\mathrm{OH}$ & $2 \cdot 7$ & $2 \cdot 6$ & $2 \cdot 0$ & $3 \cdot 0$ & $1 \cdot 8$ & $2 \cdot 9$ & $1 \cdot 6$ & $2 \cdot 5$ \\
\hline $\mathrm{C}_{16: 0} 2-\mathrm{OH}$ & $0 \cdot 8$ & $0 \cdot 9$ & ND & $1 \cdot 3$ & ND & ND & ND & ND \\
\hline $\mathrm{C}_{16: 0} 3-\mathrm{OH}$ & $1 \cdot 9$ & $1 \cdot 8$ & $0 \cdot 8$ & $1 \cdot 1$ & $0 \cdot 5$ & $1 \cdot 9$ & $1 \cdot 9$ & $0 \cdot 7$ \\
\hline iso- $\mathrm{C}_{16: 0} 3-\mathrm{OH}$ & $1 \cdot 7$ & $1 \cdot 8$ & $1 \cdot 9$ & $3 \cdot 3$ & $1 \cdot 0$ & $2 \cdot 8$ & $0 \cdot 9$ & $3 \cdot 1$ \\
\hline iso- $\mathrm{C}_{17: 0} 3-\mathrm{OH}$ & $7 \cdot 5$ & $8 \cdot 0$ & $6 \cdot 4$ & $7 \cdot 8$ & $5 \cdot 9$ & $9 \cdot 2$ & $6 \cdot 4$ & $5 \cdot 9$ \\
\hline \multicolumn{9}{|c|}{ Summed features ${ }^{\star}$} \\
\hline 3 & $29 \cdot 0$ & $29 \cdot 5$ & $24 \cdot 6$ & $33 \cdot 7$ & $20 \cdot 4$ & $22 \cdot 3$ & $22 \cdot 2$ & $19 \cdot 0$ \\
\hline 4 & $1 \cdot 5$ & $1 \cdot 6$ & $1 \cdot 6$ & $1 \cdot 3$ & $1 \cdot 8$ & $0 \cdot 9$ & $1 \cdot 7$ & $2 \cdot 7$ \\
\hline
\end{tabular}

${ }^{\star}$ Summed features represent groups of two or three fatty acids which could not be separated by GLC with the MIDI system. Summed feature 3 contained $\mathrm{C}_{16: 1} \omega 7 c$ and/or iso- $\mathrm{C}_{15: 0} \quad 2-\mathrm{OH}$; summed feature 4 contained iso- $\mathrm{C}_{17: 1} \mathrm{I}$ and/or anteiso- $\mathrm{C}_{17: 1} \mathrm{~B}$.

\section{Description of Algoriphagus locisalis sp. nov.}

Algoriphagus locisalis (lo.ci.sa'lis. L. n. locus place, locality; L. gen. n. salis of salt; N.L. gen. n. locisalis from a place of salt).

Cells are Gram-negative, non-flagellated rods that are $0 \cdot 4-0.7 \times 1 \cdot 5-3.0 \mu \mathrm{m}$ in size. Non-motile. Colonies are circular, convex, smooth, glistening, orange-coloured and $1 \cdot 0-1.8 \mathrm{~mm}$ in diameter after 3 days incubation on MA at $30^{\circ} \mathrm{C}$. Optimum growth temperature is $30^{\circ} \mathrm{C}$; growth occurs at 4 and $35^{\circ} \mathrm{C}$, but not at $36^{\circ} \mathrm{C}$. The optimal $\mathrm{pH}$ for growth is between $\mathrm{pH} 7 \cdot 0$ and 8.0 ; growth is observed at $\mathrm{pH} 5 \cdot 5$, but not at $\mathrm{pH} 5 \cdot 0$. Optimal growth occurs in the presence of $2 \%(\mathrm{w} / \mathrm{v}) \mathrm{NaCl}$; growth does not occur in the presence of $>9 \%(\mathrm{w} / \mathrm{v}) \mathrm{NaCl}$. Growth does not occur under anaerobic conditions on MA or MA supplemented with nitrate. Aesculin and Tweens 20, 40 and 60 are hydrolysed. Hypoxanthine, xanthine, tyrosine and urea are not hydrolysed. Susceptible to chloramphenicol. DCellobiose, D-fructose, maltose, sucrose and salicin are utilized as carbon and energy sources, but D-galactose, Dxylose, acetate, benzoate, pyruvate, succinate, formate and L-glutamate are not. Utilization of D-trehalose is variable (positive for type strain). Acid is produced from D-mannose and weakly produced from D-fructose and D-raffinose. No acid is produced from D-melezitose, D-ribose, myo-inositol, D-mannitol or D-sorbitol. Acid production from D-trehalose is variable (positive for type strain). The predominant menaquinone is MK-7. The major fatty acids are iso- $\mathrm{C}_{15: 0}$ and $\mathrm{C}_{16: 1} \omega 7 c$ and/or iso- $\mathrm{C}_{15: 0}$ 2-OH. The DNA G+C content is $42 \mathrm{~mol} \%$. Other phenotypic properties are given in Table 1.

The type strain, MSS $-170^{\mathrm{T}} \quad\left(=\mathrm{KCTC} \quad 12310^{\mathrm{T}}=\mathrm{JCM}\right.$ $\left.12597^{\mathrm{T}}\right)$, was isolated from sea water from a marine solar saltern of the Yellow Sea in Korea.

\section{Acknowledgements}

This work was supported by the 21C Frontier Program of Microbial Genomics and Applications (grant MG02-0401-001-1-0-0) from the Ministry of Science and Technology (MOST) of the Republic of Korea.

\section{References}

Bowman, J. P. (2000). Description of Cellulophaga algicola sp. nov., isolated from the surfaces of Antarctic algae, and reclassification of Cytophaga uliginosa (ZoBell and Upham 1944) Reichenbach 1989 as Cellulophaga uliginosa comb. nov. Int J Syst Evol Microbiol 50, 1861-1868.

Bowman, J. P., Nichols, C. M. \& Gibson, J. A. E. (2003). Algoriphagus ratkowskyi gen. nov., sp. nov., Brumimicrobium glaciale gen. nov., sp. nov., Cryomorpha ignava gen. nov., sp. nov. and Crocinitomix catalasitica gen. nov., sp. nov., novel flavobacteria isolated from various polar habitats. Int J Syst Evol Microbiol 53, 1343-1355.

Bruns, A., Rohde, M. \& Berthe-Corti, L. (2001). Muricauda ruestringensis gen. nov., sp. nov., a facultatively anaerobic, appendaged bacterium from German North Sea intertidal sediment. Int J Syst Evol Microbiol 51, 1997-2006.

Cowan, S. T. \& Steel, K. J. (1965). Manual for the Identification of Medical Bacteria. London: Cambridge University Press.

Ezaki, T., Hashimoto, Y. \& Yabuuchi, E. (1989). Fluorometric deoxyribonucleic acid-deoxyribonucleic acid hybridization in microdilution wells as an alternative to membrane filter hybridization in which radioisotopes are used to determine genetic relatedness among bacterial strains. Int J Syst Bacteriol 39, 224-229.

Komagata, K. \& Suzuki, K. (1987). Lipid and cell wall analysis in bacterial systematics. Methods Microbiol 19, 161-207.

Lanyi, B. (1987). Classical and rapid identification methods for medically important bacteria. Methods Microbiol 19, 1-67.

Leifson, E. (1963). Determination of carbohydrate metabolism of marine bacteria. J Bacteriol 85, 1183-1184.

Nedashkovskaya, O. I., Vancanneyt, M., Van Trappen, S. \& 7 other authors (2004). Description of Algoriphagus aquimarinus sp. nov., 
Algoriphagus chordae sp. nov. and Algoriphagus winogradskyi sp. nov., from sea water and algae, transfer of Hongiella halophila Yi and Chun 2004 to the genus Algoriphagus as Algoriphagus halophilus comb. nov. and emended descriptions of the genera Algoriphagus Bowman et al. 2003 and Hongiella Yi and Chun 2004. Int J Syst Evol Microbiol 54, 1757-1764.

Reichenbach, H. (1992). The order Cytophagales. In The Prokaryotes. A Handbook on the Biology of Bacteria: Ecophysiology, Isolation, Identification, Applications, 2nd edn, pp. 3631-3675. Edited by A. Balows, H. G. Trüper, M. Dworkin, W. Harder \& K. H. Schleifer. New York: Springer.

Sasser, M. (1990). Identification of bacteria by gas chromatography of cellular fatty acids. Newark, DE: MIDI.

Stackebrandt, E. \& Goebel, B. M. (1994). Taxonomic note: a place for DNA-DNA reassociation and 16S rRNA sequence analysis in the present species definition in bacteriology. Int J Syst Bacteriol 44, 846-849.

Tamaoka, J. \& Komagata, K. (1984). Determination of DNA base composition by reverse-phase high-performance liquid chromatography. FEMS Microbiol Lett 25, 125-128.

Van Trappen, S., Vandecandelaere, I., Mergaert, J. \& Swings, J. (2004). Algoriphagus antarcticus sp. nov., a novel psychrophile from microbial mats in Antarctic lakes. Int J Syst Evol Microbiol 54, 1969-1973.

Wayne, L. G., Brenner, D. J., Colwell, R. R. \& 9 other authors (1987). International Committee on Systematic Bacteriology. Report of the ad hoc committee on reconciliation of approaches to bacterial systematics. Int J Syst Bacteriol 37, 463-464.

Yi, H. \& Chun, J. (2004). Hongiella mannitolivorans gen. nov., sp. nov., Hongiella halophila sp. nov. and Hongiella ornithinivorans sp. nov., isolated from tidal flat sediment. Int J Syst Evol Microbiol 54, 157-162.

Yoon, J.-H., Kim, H., Kim, S.-B., Kim, H.-J., Kim, W. Y., Lee, S. T., Goodfellow, M. \& Park, Y.-H. (1996). Identification of Saccharomonospora strains by the use of genomic DNA fragments and rRNA gene probes. Int J Syst Bacteriol 46, 502-505.

Yoon, J.-H., Lee, S. T. \& Park, Y.-H. (1998). Inter- and intraspecific phylogenetic analysis of the genus Nocardioides and related taxa based on 16S rRNA gene sequences. Int J Syst Bacteriol 48, 187-194.

Yoon, J.-H., Kim, I.-G., Shin, D.-Y., Kang, K. H. \& Park, Y.-H. (2003). Microbulbifer salipaludis sp. nov., a moderate halophile isolated from a Korean salt marsh. Int J Syst Evol Microbiol 53, 53-57.

Yoon, J.-H., Kang, S.-J., Jung, S.-Y., Lee, C.-H. \& Oh, T.-K. (2005). Algoriphagus yeomjeoni sp. nov., isolated from a marine solar saltern in the Yellow Sea, Korea. Int J Syst Evol Microbiol 55, 865-870.

Yurkov, V., Stackebrandt, E., Holmes, A. \& 7 other authors (1994). Phylogenetic positions of novel aerobic, bacteriochlorophyll a-containing bacteria and description of Roseococcus thiosulfatophilus gen. nov., sp. nov., Erythromicrobium ramosum gen. nov., sp. nov., and Erythrobacter litoralis sp. nov. Int J Syst Bacteriol 44, 427-434. 